\title{
An Overview of Post-Legislative Scrutiny in Western Australia
}

Hon. Kate Doust MLC

Legislative Council of Western Australia

Email: president@parliament.wa.gov.au

Sam Hastings

Parliament of Western Australia

Email: shastings@parliament.wa.gov.au

\begin{abstract}
:
Twenty years ago, the House of Lords Select Committee into the Constitution focused attention back onto the concept of post-legislative scrutiny. Since then, a clear framework and momentum for systematic post-legislative scrutiny has developed which has enabled parliaments to strengthen their role in the legislative process. However, there is a dearth of academic research into post-legislative scrutiny in Australian jurisdictions. Currently, there is no clear picture of the extent of post-legislative scrutiny in Western Australia and the factors in support, and challenges in implementing, systematic review of legislation. This article examines the extent of post-legislative scrutiny conducted by or overseen by the Parliament of Western Australia. An analysis of review reports and parliamentary debates reveals the outcomes of post-legislative scrutiny by the Executive. This article also examines outcomes of post-legislative scrutiny conducted by parliament through the application of the Westminster Foundation for Democracy's Principles of Post-Legislative Scrutiny. Finally, barriers to post-legislative scrutiny by the legislature and options for reform are explored.
\end{abstract}

Keywords: Post-legislative scrutiny, Western Australia, review clauses.

\section{POST-LEGISLATIVE SCRUTINY}

Post-legislative scrutiny is, at its simplest, the process of review of the effects of legislation post-enactment. ${ }^{1}$ In an end-to-end approach to the legislative process, post-legislative scrutiny can help to determine whether the government has fully implemented legislation as intended and identify unintended consequences from its implementation. This can inform the need for further legislation or legislative revision. ${ }^{2}$ In this sense, post-legislative scrutiny is both a legislative and an oversight

1 United Kingdom, The Law Commission, Post-Legislative Scrutiny, (London: The Law Commission, 2006) at 2.4.

2 Jonathan Murphy \& Svitlana Mishura, "Post Legislative Scrutiny in a Non-Westminster Environment” (2019) 21(2) European Journal of Law Reform 102 at 105-106. 
activity for parliament and is about the accountability of, and accountability to, the parliament. $^{3}$

Despite significant levels of attention in recent time, the concept of parliament reviewing legislation post-enactment is not a new concept. There are many examples of post-legislative scrutiny occurring in the United Kingdom and European countries on ad hoc basis over the last 30 years. As early as the 1970s, the House of Commons considered the need for committees to undertake postlegislative scrutiny. ${ }^{4}$ There were further calls from committees for post-legislative scrutiny in $1997^{5}$ and $2002^{6}$. The House of Lords Select Committee on the Constitution tabled a comprehensive report on legislative scrutiny in 2004 and made four principal recommendations:

1. Each bill should have an explanatory note setting out the purpose of the bill and the criteria under which it can at some future time be assessed as to whether it has met its purpose.

2. Most Acts other than finance Acts should be reviewed within three years after their enactment. ${ }^{8}$

3. Acts should be reviewed by relevant government departments against the criteria in the explanatory note after conducting public consultation. A memorandum should be lodged with the relevant departmental standing committee. ${ }^{9}$

4. Standing committees should have the discretion to undertake their own evidence-based inquiries in light of the departmental review and be resourced appropriately to do so..$^{10}$

These principles were echoed in a review of post-legislative scrutiny conducted by the Law Commission. ${ }^{11}$ They largely form the basis of a formalised system of post-legislative scrutiny in the United Kingdom today. ${ }^{12}$

$3 \quad$ Ibid at 107.

4 House of Commons, Select Committee on Procedure, The Process of Legislation, (28 July 1971) (Chair: Robin Turton) at ix.

5 House of Commons, Select Committee on the Modernisation of the House of Commons, 1st Report on the Legislative Process (29 July 1997) (Chair: Ann Taylor).

6 House of Commons, Select Committee on Liaison, Annual Report for 2002 (20 March 2003) (Chair: Alan Williams).

7 House of Lords, Select Committee on the Constitution, Parliament and the Legislative Process, (29 October 2004) at para 87 (Chair: Lord North of Nouth).

$8 \quad$ Ibid at para 180.

$9 \quad$ Ibid at para 189-190.

10 Ibid at para 191-192.

11 The Law Commission, supra note 3.

12 Office of the Leader of the House of Commons, Post-legislative Scrutiny - The Government's Approach, (London: Office of the Leader of the House of Commons, 2008) online: https://assets.publishing.service.gov.uk/government/uploads/system/uploads/attachment_data/fi le/228516/7320.pdf. 
Proponents of post-legislative scrutiny highlight several benefits to the legislative process including asserting parliament's role in the whole legislative process, better regulatory outcomes to match the effort put into pre-enactment regulatory impact assessment, ${ }^{13}$ salutary effects on the Executive to focus their minds on how they will implement laws prior to their enactment, ${ }^{14}$ the monitoring of issues identified by legislators during consideration of the bill ${ }^{15}$ and to learn lessons to be implemented in future law-making activity. ${ }^{16}$

\section{What are the Different Approaches to Post-Legislative Scrutiny?}

There is a growing body of academic studies assessing the efficacy of different approaches to post-legislative scrutiny. Some cross-jurisdictional studies are evolving, which enable worldwide best practice to be identified. ${ }^{17}$

Principal to the differences between post-legislative scrutiny approaches is the scope adopted by the review body. Griglio attempts to classify post-legislative scrutiny by parliaments into three categories. The first, passive post-legislative scrutiny, is where a parliament limits their role to the assessment of scrutiny conducted by government bodies or external agencies. ${ }^{19}$ Secondly, informal scrutinisers are parliaments where there are established ad hoc administrative parliamentary structures for post-legislative scrutiny..$^{20}$ Finally, formal scrutineers have post-legislative scrutiny occurring in a formal and institutionalised manner. ${ }^{21}$

There are many views on the manner in which post-legislative scrutiny should be conducted and the considerations for any review. Some consider that technical questions should be central such as unintended legal consequences or interpretive difficulties along with evaluative questions including whether policy objectives have been met and the economic costs of the legislation. ${ }^{22}$ Others express these

13 Geoffrey Palmer, "Law-Making in New Zealand: Is There a Better Way" (2014) 22 Waikato Law Review 1 at 30.

14 Angus Francis, "The Review of Australia's Asylum Laws and Policies: A case for Strengthening Parliament's Role in Protecting Rights Through Post-Enactment Scrutiny" (2008) 32(1) Melbourne University Law Review 83 at 92.

15 Ibid at 92.

16 Select Committee on the Constitution, supra note 9 at para 172.

17 Westminster Foundation for Democracy, Post-Legislative Scrutiny: Comparative study of practices of Post-Legislative Scrutiny in selected parliaments and the rationale for its place in democracy assistance, (London: Westminster Foundation for Democracy, 2017) by Franklin De Vrieze and Victoria Hasson.

18 Elena Griglio, "Post-Legislative Scrutiny as a Form of Executive Oversight" (2019) 21(2) European.Journal of Law Reform 118.

19 Ibid at 124.

20 Ibid at 126.

21 Ibid at 129.

22 Palmer, supra note 15 at 31. Also, Christopher Finlayson, "Making better law in New Zealand" (2006) 3 The Parliamentarian 232 at 235. 
considerations in terms of effectiveness, efficacy and efficiency. ${ }^{23}$ There is also a question of whether legislation should be evaluated against general principles, such as those against which pre-legislative scrutiny is conducted, ${ }^{24}$ or pre-set criteria around the purpose and policy of the bill. ${ }^{25}$

\section{The Westminster Foundation for Democracy's Model of Post- Legislative Scrutiny}

A strong proponent of post-legislative scrutiny is the Westminster Foundation for Democracy, a public body established in the United Kingdom to promote and support democracy around the world.

In 2018 the Westminster Foundation for Democracy developed a guidance document for parliaments who were considering conducting post-legislative scrutiny, collating best practice from jurisdictions already engaging in the practice. The guidance document contains 15 principles under five main headings mandate (why), scope (what), participants (who), processes (how) and timing (when). The guidance document states that its principles are not, 'exhaustive nor exclusive but are intended to provide guidance in establishing realistic post-leg practices. $^{26}$

\section{THE WESTERN AUSTRALIAN PARLIAMENT}

Western Australia has a bicameral parliament with a Lower House, the Legislative Assembly, made up of single-member constituencies and an Upper House, the Legislative Council, made up of multi-member constituencies elected using proportional representation. The effect of this is that the party with a majority of Members in the Legislative Assembly forms the government and may have to work with a Legislative Council where it does not have a majority of Members. The Legislative Council follows the Westminster tradition of upper houses and is regarded as a house of scrutiny and review. ${ }^{27}$ There are some structural checks on the Upper House's ability to legislate. Bills that seek to appropriate money must originate in the Legislative Assembly. ${ }^{28}$ In addition, it is rare for bills not supported

23 Luzius Mader, "Evaluating the Effects: A Contribution to the Quality of Legislation" (2001) 22(2) Statute Law Review 119 at 126.

24 For example, Legislative Standards Act, Queensland 1992 s 4

25 Francis, supra note 16 at 87.

26 Westminster Foundation for Democracy, Principles of Post-Legislative Scrutiny by Parliaments, (London: Westminster Foundation for Democracy, 2018) by Franklin De Vrieze at 2

27 Western Australia, Commission on Government, Report No.2, (Perth: Commission on Government, 1995) online: <https://www.slp.wa.gov.au/publications/publications.nsf/DocByAgency/D7065CDD58C78754 4825698300109D09/\$file/report2.pdf $\geq$ at 240 .

28 Constitution Acts Amendment Act, Western Australia 1899, s 46. 
by the government to become law as they must pass the government-controlled Lower House.

Before a bill gets to parliament, a proposal goes through a Cabinet process with a regulatory impact statement to inform policy makers of the costs and benefits of the proposed regulatory action. ${ }^{29}$ These regulatory impact statements often involve public consultation and are recommended to be made public. ${ }^{30}$

Once introduced to the House, a bill may receive scrutiny in a number of ways. Firstly, Members may ask questions on any provision of the bill while the bill is being considered clause by clause by the whole House. The Standing Orders of the Legislative Council provide for unlimited periods of time for Members to ask questions on specific provisions of bills, so long as the questions are not repetitive. ${ }^{31}$ In addition, the Legislative Council does not countenance the use of the 'guillotine' by the government to reduce the opportunity for scrutiny. A bill can be referred to one of the parliament's standing committees for detailed scrutiny and reporting back to the House. The Legislative Council has three standing parliamentary committees whose primary function is scrutiny of bills. ${ }^{32}$ These committees are supported by professional staff with technical expertise in the traditional legaleconomic fields. ${ }^{33}$ The positions are funded through a government appropriation made to the Legislative Council by the government each year. ${ }^{34}$

\section{POST-LEGISLATIVE SCRUTINY IN WESTERN AUSTRALIA}

Western Australia largely has a set and forget model of regulation. ${ }^{35}$ While there is no systemic framework for post-legislative scrutiny in Western Australia, this activity is occurring ad hoc but is not inventoried. ${ }^{36}$ It predominately occurs through Executive-led review of legislation. However, this approach has its pitfalls, particularly around timeliness and independence. In limited circumstances, parliament has elected to conduct its own post-legislative scrutiny activity with limited results.

29 Western Australia, Regulatory Gatekeeping Unit, Regulatory Impact Assessment Guidelines for Western Australia, (Perth: Regulatory Gatekeeping Unit, 2010) at 4.

$30 \quad$ Ibid at 15.

31 Legislative Council of Western Australia, Standing Orders at SO 22.

32 The Legislation Committee, the Joint Delegated Legislation Committee and the Uniform Legislation and Statutes Review Committee.

33 Griglio, supra note 20 at 127.

34 In 2019-20 the appropriation for the Legislative Council to deliver its functions is $\$ 6.499$ million. See Western Australia, Department of Treasury, Budget Paper No.2 Volume 2, (Perth: Department of Treasury, 2019) at 31.

35 Charles Chauvel, "Post-Legislative Scrutiny in New Zealand - A Focus on Delegated Legislation” (2019) 21(2) European Journal of Law Reform 169 at 172.

36 Murphy \& Mishura, supra note 4 at 111. 


\section{Review by the Executive}

A majority of reviews on the impact and effectiveness of legislation are conducted by the Executive. These reviews are almost always done pursuant to a review clause in legislation that requires the Minister to review an Act, sometimes considering certain criteria, and to table it in parliament once complete. Parliamentary scrutiny of these reviews would be categorised as passive scrutiny by Griglio. ${ }^{37}$

The parliament has not provided comprehensive direction to the Executive about its expectations for statutory reviews. To assist government departments to conduct statutory reviews the State's Public Sector Commission produced a guideline document. ${ }^{38}$ The document sets out the process for a review of legislation including governance considerations, best practice consultation and report preparation, including finding and recommendation drafting.

Executive-led review of legislation provides many benefits to the parliament and can help to overcome the barriers to greater levels of parliament-led postlegislative scrutiny. The two principal benefits of such reviews are the use of experts in the field who understand the technical aspects of the legislation and that the cost is borne by the Executive government. However, this must be balanced against significant trade-offs. Most prominent of these is the review's lack of independence from the Minister and the potential for influence on the process and recommendations. This is apparent in the Public Sector Commission's guidelines, which provide that departments should seek the Minister's views on whether an independent person should be appointed to conduct the review ${ }^{39}$ and that the political and fiscal environment needs to be considered when setting the terms of reference for a review. ${ }^{40}$ Unless specified in the enabling Act, parliament has no control over the terms of reference for the review, meaning parliament's concerns with the original bill, sought to be addressed through the insertion of a review clause, may not be central to the review. Parliament also has no recourse against a Minister if a review is not completed on time, or at all.

In assessing the effectiveness of Executive-led review as a means of postlegislative scrutiny by parliament, critical considerations include the number of reviews completed, the timeliness of the reviews and the engagement of the parliament in considering and debating the outcomes of the reviews.

\section{a. Data}

In order to assess the efficacy of Executive-led reviews as a method of postlegislative scrutiny, a data set was compiled concerning Executive-led reviews

37 Griglio, supra note 20 at 124.

38 Western Australia, Public Sector Commission, Guidelines for the Review of Legislation, (Perth: Public Sector Commission, 2013).

39 Ibid at 11.

40 Ibid at 12. 
legislated by parliament. This data set considers review clauses in bills passed between 2001 and 2012 ( $36^{\text {th }}$ to $38^{\text {th }}$ parliaments).

Figure 1 shows the incidence of Executive-led reviews of Acts and the timeliness of those reviews. This data was compiled through keyword searching of legislative databases and detailed searching of the Parliament of Western Australia's tabled papers database.

Figure 1 - Incidence of review clauses and timeliness of reviews

\begin{tabular}{|l|c|}
\hline Number of Acts passed & 706 \\
\hline Number of Acts containing Executive-led review clauses & 68 \\
\hline Number of reviews undertaken, and reports tabled & $34^{*}$ \\
\hline Acts repealed before review was due or the review is not yet due & 16 \\
\hline Reviews not completed & 18 \\
\hline Number of reviews tabled on time & 9 \\
\hline Mean overdue period of reports tabled & 3 years \\
\hline Mean overdue period of reports not yet tabled & 5.1 years \\
\hline
\end{tabular}

* One review was completed but not tabled in parliament, it is deemed tabled for the purpose of this research.

Figure 2 illustrates the engagement of Members of the Parliament of Western Australia with Executive-led reviews. This data is compiled from Hansard and select committee records.

Figure 2 - Parliamentary debate on tabled reviews

\begin{tabular}{|l|c|}
\hline $\begin{array}{l}\text { Number of reviews discussed in parliament within two years after } \\
\text { tabling }\end{array}$ & 12 \\
\hline $\begin{array}{l}\text { Number of reviews discussed in parliament more than two years } \\
\text { after tabling }\end{array}$ & 8 \\
\hline $\begin{array}{l}\text { Number of reviews resulting in further scrutiny of the Act by a } \\
\text { select committee }\end{array}$ & 0 \\
\hline
\end{tabular}

Figure 3 illustrates the impact of breadth of Executive-led review clauses. Review clauses were categorised as specific or broad. A specific review clause is a 
clause that requires the Minister to take into account specific considerations when conducting the review. A broad review clause is a clause that requires the Minister to review the 'operation and effectiveness' of the Act. This data is compiled from legislative databases and the Parliament of Western Australia's tabled papers database.

Figure 3 - Content of review clauses

\begin{tabular}{|l|l|l|l|l|}
\hline & Incidence & $\begin{array}{l}\text { Number of } \\
\text { reviews tabled }\end{array}$ & $\begin{array}{l}\text { Tabled on } \\
\text { time }\end{array}$ & $\begin{array}{l}\text { Average time } \\
\text { overdue }\end{array}$ \\
\hline $\begin{array}{l}\text { Specific review } \\
\text { clause }\end{array}$ & 26 & 17 & 5 & 3.17 years \\
\hline $\begin{array}{l}\text { Broad review } \\
\text { clause }\end{array}$ & 26 & 17 & 4 & 2.9 years \\
\hline
\end{tabular}

\section{b. Analysis}

The number of Acts containing review clauses (68 of 706) shows that parliament is very selective about the bills that it considers will require review.

Despite the infrequent wish of parliament for Acts to be reviewed, this does not translate into compliance. As shown in Figure 1, the use of Executive-led review clauses is only moderately successful in encouraging the Executive to conduct a review. Excluding those reviews that are not yet due to be tabled, or contained in Acts that have been repealed, the completion rate of reviews is 65 per cent. The lack of power for parliament to compel the conduct of a review may be causative of the Executive's approach to the timelines of reviews tabled. Only 9 of 34 reviews were tabled within the time set out in the review clause. The mean period that late reports were tabled was three years, representing almost a whole four-year term of parliament. There are many longstanding overdue reports with the average overdue period being 5.1 years.

Once tabled, the data suggests a lack of engagement in the fruits of the reviews by Members of parliament. Only 20 of the 34 reviews tabled (59 per cent) were discussed in the parliamentary chamber. Only 12 of the 34 reviews were discussed within two years after being tabled (35 per cent).

Figure 3 indicates that the scope of the Executive-led review clause has no impact on the review's likelihood of being completed. A review clause that sets out specific considerations for the Minister is more likely to see a review tabled on time but, if the review is late, it is likely to be tabled later than a review conducted under a broad review clause. 


\section{c. Discussion}

The data on legislative reviews for the $36^{\text {th }}$ to $38^{\text {th }}$ parliaments does not support a conclusion that the current system of Executive-led review is fully enabling parliament to perform its scrutiny function. The Executive's disregard for the parliament is demonstrated through three in ten reviews not being conducted and over 80 per cent of reviews being tabled late. It could not be argued that the Executive is overburdened with review activity as the Executive is required to table, on average, three reviews each year.

Parliament must shoulder some responsibility for the deficiencies in the process.

The legislature is inconsistent in whether it requires the Minister to take into account specific considerations or not when conducting a review of legislation. This lack of consistency may impact on government agencies' ability to develop consistent guidelines as to how they respond to legislative reviews. Despite this variation in the form of the reviews, it does not appear to impact on the likelihood of completion or timeliness.

The parliament also has a role in engaging with the tabled reviews during parliamentary business. Executive-led reviews are costly and time-intensive. The parliament's discussion of only 35 per cent of reviews within two years of tabling does not indicate great interest in the work of the reviewers, which could lead to apathy. The reasons for the lack of enthusiasm for parliamentary consideration of reviews requires further research. This research could explore possible factors including dissatisfaction with the content of reviews, a lack of a clear mechanism under the standing orders to require a review to be considered or a lack of understanding or awareness of reviews. By never forming a select committee to inquire into late or incomplete reviews, parliament has not flexed its muscle to encourage future compliance.

While not the subject of this analysis, it is noted that only 2 of the 68 review clauses called for a review of whether the policy objectives of the Act were still valid and whether the provisions of the Act still met those policy objectives - a principal question which is the main thrust of many of the post-legislative scrutiny bestpractice principles. It is also noted that neither of the two reviews under such clauses have been tabled.

\section{Review by the Parliament}

Parliament-led post legislative scrutiny is an uncommon occurrence in the Legislative Council of Western Australia with only four post-legislative scrutiny inquiries being conducted in the last 20 years. In each case, the scrutiny work has been undertaken by a select or standing committee. This work would be classified by Griglio's as informal scrutinisers activity. ${ }^{41}$ Despite all four of the reviews being

41 Griglio, supra note 20 at 126. 
provided for in their enabling Acts, each review took a different path with limited outcomes.

The Legislative Council's approach is examined in each of the four examples using the five categories of principles of post-legislative scrutiny espoused by the Westminster Foundation for Democracy. ${ }^{42}$ The impact of the four cases of post-legislative scrutiny by parliament is considered to inform possibilities for reform.

\section{a. Mandate}

The Legislative Council is empowered to conduct any scrutiny activity it desires, with the question always coming back to the politics of the numbers in the House. As the government often does not have a majority in the Upper House, there is the potential for the establishment of select committees against the government's wishes. Despite this power, in the last 20 years the House has not referred an Act to a select or standing committee for post-legislative scrutiny, nor has a committee used its own-motion power to inquire specifically into an Act. Each of the four case study examples arose through a review clause in legislation requiring the review to be conducted by a parliamentary committee.

The Legislative Council has several mechanisms available to it to compel postlegislative review. Sunset clauses, while a useful devices, are very infrequently used in Western Australian legislation and delegated legislation, only generally in taxing Acts, $^{43}$ Acts with cross-jurisdictional application ${ }^{4}$ or where extraordinary powers are being granted. ${ }^{45}$ Unlike the Australian Federal Parliament there is no automatic sunsetting of legislative instruments. ${ }^{46}$ Sunset clauses are occasionally raised by Members in debate, usually on the most contentious of bills and usually by opposition Members. As one opposition Member noted, 'A sunset clause is not a dangerous device; it is a simple and sensible mechanism'. ${ }^{47}$ In reality, without the support of the government, these devices are rarely used.

Ministerial undertakings to review legislation are also a rare occurrence. With an established system of Executive-led reviews, there is often little need for a Minister to undertake to review an Act, rather the government will enshrine a future review in the Act itself. ${ }^{48}$

42 Westminster Foundation for Democracy, supra note 28

43 Land Legislation Amendment (Taxing) Act, Western Australia 2014.

44 Mutual Recognition (Western Australia) Act, Western Australia 2010.

45 Terrorism (Extraordinary Powers) Act, Western Australia 2005.

46 Legislation Act, Commonwealth of Australia 2003 s 50.

47 Western Australia, Legislative Assembly, Hansard, (7 May 2003) at 7214 (Max Trenorden).

48 For example, see Suitors' Fund Amendment Bill, Western Australia 2017. 


\section{b. Scope}

Analysis of the debate surrounding the passing of the enabling Acts does not reveal any clear, consistent rationale for the inclusion of a clause requiring parliament, rather than the Executive, to review the Acts.

In 2003, the parliament considered the Racing and Wagering Western Australia Bill 2003 and an associated Act. The bill, as presented to parliament, contained a broad Executive-led review clause. Parliament amended the clause to require that the review be conducted independently. The opposition suggested an amendment to insert a sunset clause to wind up the activities enabled under the Act if a review of the industry was not conducted. ${ }^{49}$ This amendment, described as a 'Sword of Damocles', ${ }^{50}$ was ultimately not moved. A Member successfully moved an amendment requiring the review to be conducted by a joint committee of parliament rather than the Minister. ${ }^{51}$ Parliament debated the merits of this method of review for some time. Members indicated that they had received representations by stakeholders that they would prefer that parliament lead the review. ${ }^{52}$ The opposition was concerned about government influence over the outcomes of the report, suggesting that while a joint committee of both Houses was preferable to a review conducted by the Minister or the government controlled Lower House. ${ }^{53}$ The opposition acknowledged that the government had no obligation to adopt any of the recommendations but that the report would, 'be available to the public to judge and will provide an element of oversight and safeguard that should provide some comfort to the industry'.

There was less debate and consideration of parliament-led post-legislative scrutiny when the parliament considered the State Administrative Tribunal Bill 2004, a bill establishing an administrative review tribunal. The bill was a substantial piece of government reform, amending 142 Acts and in doing so was the largest ever bill, to that date, introduced to the parliament. ${ }^{55}$ The bill was referred to the Standing Committee on Legislation for pre-legislative scrutiny. In its report, the Standing Committee recommended, 'there would be some benefit in providing a requirement in the State Administrative Tribunal Bill 2004 for a parliamentary review of the jurisdiction and operation of the proposed SAT after the SAT has been in operation for two years' and that a clause be inserted into the bill to achieve this. ${ }^{56}$ The committee did not provide any rationale for this view except to indicate

49 Western Australia, Legislative Council, Hansard, (12 June 2003) at 8670 (Hon Barry House).

50 Western Australia, Legislative Assembly, Hansard, (7 May 2003) at 7217 (Hon John Kobelke).

51 Western Australia, Legislative Council, Hansard, (12 June 2003) at 8671 (Hon Jim Scott).

52 Ibid.

53 Legislative Council, supra no 51 at 8671.

54 Ibid

55 Western Australia, Legislative Assembly, Hansard, (24 June 2003) at 9104 (Hon Jim McGinty).

56 Legislative Council of Western Australia, Standing Committee on Legislation, State Administrative Tribunal Bill 2003 and the State Administrative Tribunal (Conferral of Jurisdiction) Amendment and Repeal Bill 2003, (29 October 2004) (Chair: Hon Jon Ford). 
that the approach mirrored the approach taken with similar legislation from another jurisdiction. ${ }^{57}$ When the committee's recommendation was considered in both Houses, the Act was amended without debate. ${ }^{58}$

Parliamentary committees gave some insight into the reasons for parliament-led post-legislative scrutiny when they considered two related bills in 2006. In November 2005 the government tabled green bills (draft legislation) for the Financial Management Bill 2005 and the Auditor General Bill 2005. The Public Accounts Committee resolved to inquire into both bills. ${ }^{59}$ The Financial Management Bill 2005 provided for Executive-led review. The Auditor General Bill 2005 did not contain a review clause.

In its report on the Financial Management Bill 2005, the committee recommended that the Minister's review be, 'referred to the Public Accounts Committee of the day to enable detailed consideration of any issues it identifies ${ }^{90}$ The committee stated, 'Some of these issues go to the heart of the relationship between the Executive and Parliament and the Committee believes Parliament, more particularly the Public Accounts Committee or its successor, should conduct its own review'. ${ }^{61}$ This approach was included in the bill when it was passed.

In its report into the Auditor General Bill 2005 the committee recommended that a review clause be inserted which required the Public Accounts Committee to conduct a review of the Act after five years. ${ }^{62}$ The committee stressed that the review should not be done by the Minister because of, 'the over-riding importance of protecting the independence of the Auditor General'. ${ }^{63}$ The government accepted the recommendation of the committee and included a review clause, as drafted by the committee, into the final bill. That review clause was broadened in the Legislative Council to require a review of the Act every five years and require the committee to appoint a suitably qualified person to conduct a performance and legislative review of the Auditor General's functions. ${ }^{64}$

There is little that can be discerned from the parliament's approach to postlegislative scrutiny in each of the four case studies. While in each case, parliamentled post-legislative scrutiny was not a feature of the original bill, once an amendment was moved it was accepted by the government with little to no debate.

57 Administrative Decisions Tribunal Act, New South Wales 1997.

58 Western Australia, Legislative Council, Hansard, (10 November 2004) at 7775; Western Australia, Legislative Assembly, Hansard, (10 November 2004) at 7887.

59 Western Australia, Legislative Assembly, Hansard, (23 November 2005) at 7655.

60 Legislative Assembly of Western Australia, Public Accounts Committee, Review of the Financial Management Bill 2005 and the Auditor General Bill 2005, (6 April 2006) at 34 (Chair: John Quigley).

61 Ibid

62 Ibid at 66.

63 Ibid at 65.

64. Western Australia, Legislative Council, Hansard, (7 December 2006) at 9330 (Hon Kim Chance). 
The limited or absent rationale for post-legislative review by parliament does not provide any guidance on which bills might be suitable for post-legislative review in the future. As with many unexplained outcomes in democratic institutions, this could be a reminder that politics, even if not seen, is at the heart of a parliament's work. ${ }^{65}$

Likewise, there is no clear rationale behind the scope of the review clauses. In three of the case studies, a narrow review clause required a review of either the 'operation and effectiveness of the Act' or 'jurisdiction and operation'. The review clause in the Auditor General Act 2006 was more specific, containing two pages of the factors that the review was to have regard to and setting out detail about the performance audit and legislative review.

None of the reviews conducted clearly articulated the policy of the bills and whether the policy objectives had been achieved. Some reviews recommended amendments to delegated legislation, not a as a result of technical analysis but as a result of feedback from stakeholders in relation to the operation or effectiveness of the Act. Each of the reviews primarily considered the relevant Acts being reviewed, as opposed to how the Acts broadly affect different groups in society.

\section{c. Participants}

There is no single committee responsible for post-legislative scrutiny in the Legislative Council, although standing orders provide the opportunity for some committees to elect to conduct this work. There is no dedicated body to support post-legislative scrutiny activity separate from the Legislative Council's committee secretariat who support the Council's other committee inquiries. This group is well resourced by the parliament's corporate functions, but post-legislative scrutiny work competes for resources against the Legislative Council's other committees. In each of the four case studies, the reviews were supported by the committee secretariat.

The review committees took different approaches to stakeholder consultation in each of the four case studies. In the review of the Auditor General Act 2006, there was no stakeholder or public consultation undertaken. However, the committee sought the Auditor General's views on the reports prepared by consultants into the performance and legislative framework affecting the Auditor General. In the review of the Financial Management Act 2006, the committee invited public submissions and also wrote to all stakeholders that provided submissions to the Minister's review of the Act to ask if their concerns were adequately addressed by the Minister's final report and whether those issues remained current. ${ }^{66}$

65 Murphy \& Mishura, supra note 4 at 107.

66 Legislative Council and Legislative Assembly of Western Australia, Joint Standing Committee on Audit, Review of the Department of Treasury's Review of the Financial Management Act 2006, (17 March 2016) at 3 (Chair: Hon Ken Travers). 
A public consultation process was undertaken in the review of the Racing and Wagering Western Australia Act 2003. The committee called for public submissions through state-wide advertising and approached industry participants. The committee conducted 48 public hearings and heard from 111 witnesses. ${ }^{67}$ The committee also received 14 briefings from interstate racing participant organisations. ${ }^{68} \mathrm{~A}$ broader approach was undertaken in the review of the State Administrative Tribunal Act 2004, where the committee invited public submissions, wrote to all people and organisations who had been invited to or made a submission into the pre-legislative scrutiny of the original bill plus every government department and almost 2500 randomly-selected people who had been parties to proceedings before the Tribunal. ${ }^{69}$

The differences in consultation demonstrate a tailored and mature approach taking into account the cost and benefits of a broader level of consultation.

\section{d. Processes}

There are no established processes for post-legislative scrutiny activity in the Legislative Council, meaning each committee charged with post-legislative scrutiny work had to turn its mind to the depth, scope and resources to allocate to its inquiry. Despite the lack of processes, each committee in the four case studies did not seek to replay policy arguments in their reports.

In the reviews of the State Administrative Tribunal Act 2004 and the Racing and Wagering Western Australia Act 2003 the committees undertook an inquiry process that was similar to most inquiries conducted by a parliamentary committee - calling for submissions, site visits, public hearings and stakeholder consultation. The committees did not conduct a technical scrutiny of the text of the law and were more focused on the lived-experience with the operation and jurisdiction of the body they were examining ${ }^{70}$ or its future challenges. ${ }^{71}$ In the review of the Auditor General Act 2006 and Financial Management Act 2006 the committee developed its own process due to the irregularity of a parliamentary committee conducting a review of a review conducted by another entity.

None of the inquiries faced issues with access to information from the Executive.

67 Legislative Council and Legislative Assembly of Western Australia, Joint Standing Committee on The Review of the Racing and Wagering Western Australia Acts, Inquiry into the Racing and Wagering Western Australia Acts, (14 October 2010) at 3 (Chair: John McGrath).

68 Ibid at 221-222.

69 Legislative Council of Western Australia, Standing Committee on Legislation, Inquiry into the Jurisdiction and Operation of the State Administrative Tribunal, (20 May 2009) at 5-6 (Chair: Hon Ken Baston).

$70 \quad$ Ibid at 6.

$71 \quad$ Ibid at 5. 
The Legislative Council does have processes in place to ensure that the House can consider committee reports that are tabled, with dedicated time set aside for this purpose. ${ }^{72}$ The Standing Orders provide that Members have unlimited periods of ten minutes to speak to committee reports and after a report has been considered for an hour, it cycles to the back of the list of reports and can be called on for further debate at a later time. A flow on effect is that this process allows time for the government to respond to the findings and recommendations made in a report before it is debated further. This is particularly useful from a post-legislative scrutiny perspective as it enables the legislature to be confident about the government's position on recommendations and for this to be open to debate in the House.

\section{e. Timing}

In the limited number of parliament-led reviews of legislation, the review period prescribed in the legislation has been either three or five years. The reviews for the State Administrative Tribunal Act 2004 and the Racing and Wagering Western Australia Act 2003 were conducted as scheduled. The reviews for the financial Acts were severely delayed.

The Minister's review of the Financial Management Act 2006, which was due to be completed by February 2012, was completed in March 2014 but not tabled in the parliament until September 2015. ${ }^{73}$ The committee made findings about the delays and commented on the insufficiency of the reasons put forward for the delay. ${ }^{74}$ The committee completed its review of the Minister's review in August 2016, almost nine years after the law came into effect. ${ }^{75}$

The review of the Auditor General Act 2006 was commenced by the committee a year late, in 2013. After preliminary analysis, the committee reported to parliament that the cost of the review would be significant and that the Act did not provide funds for the committee to do the work. ${ }^{76}$ In 2015 the Committee sought $\$ 331,650$ to engage a consultant to conduct the performance audit aspect of the review. ${ }^{77}$ In 2016 , the committee sought $\$ 49,600$ for a consultant to conduct a legislative review. ${ }^{78}$ Both reviews were made publicly available, along with the

72 Legislative Council of Western Australia, supra note 33 at SO 15.

73 Joint Standing Committee on Audit, supra note 68 at 8.

$74 \quad$ Ibid at 1.

75 Ibid at 3.

76 Legislative Council and Legislative Assembly of Western Australia, Joint Standing Committee on Audit, Review of the Auditor General Act - Appointment of Reviewer, (17 October 2013) (Chair: Hon Ken Travers).

77 Legislative Council and Legislative Assembly of Western Australia, Joint Standing Committee on Audit, Review of the Operation and Effectiveness of the Auditor General Act 2006, (25 August 2016) at 4 (Chair: Hon Ken Travers).

$78 \quad$ Ibid at 5. 
committee's report, in mid-2016, 10 years after the Act was passed and four years late. $^{79}$

\section{f. Impact of Post-Legislative Scrutiny}

A principal benefit of post-legislative scrutiny is the identification of issues in the implementation of a law and to inform future legislation to remedy these issues. ${ }^{80}$

In order to assess the impact of post-legislative scrutiny conducted in the four case studies, data was compiled from committee reports and government responses to those reports. In particular, committee recommendations for legislative review were compiled and legislative databases were analysed to identify how many of the legislative changes recommended by the committees were implemented.

Figure 4 summarises the outcomes of this analysis.

Overall, 56 per cent of all recommendations made in the four case studies called for legislative change. Of these, just 11 per cent of the recommendations for legislative change were implemented, with eight of nine of those recommendations relating to one review. The mean time for implementation of recommendations for legislative change ranges from 55 to 88 months.

Based on this data, the post-legislative scrutiny conducted in the four case studies had very limited impact, particularly when set against the cost of conducting the reviews. While there may be salutary effects from the reviews and other immeasurable benefits, the legislative outcomes achieved compared to the legislative issues identified does not demonstrate a focus on closing gaps in the implementation of legislation.

The government's lack of action on the recommendations of the review committees could be reflected in the lack of interest in debating the committee reports tabled in both houses of parliament. The review of the State Administrative Tribunal Act 2004 was debated for one hour in the Legislative Council before the report was noted. ${ }^{81}$ Despite the breadth of the review into the Racing and Wagering Western Australia Act 2003 it was only spoken to by three Members, all Members of the review committee. ${ }^{82}$ The reviews into the Financial Management Act 2006 and Auditor General Act 2006 were tabled by the Chair or Deputy Chair of the committee and a two paragraph statement was made. ${ }^{83}$ The review into the Financial Management Act 2006 was noted in the Legislative Council a week later

79 Ibid at 4.

80 Murphy \& Mishura, supra note 4 at 105-106. Also, Mader, supra note 25 at 122.

81 Western Australia, Legislative Council, Hansard, (26 May 2010) at 3384-3385 and 3394-3400.

82 Western Australia, Legislative Assembly, Hansard, (14 October 2010) at 7753-7759.

83 Western Australia, Legislative Assembly, Hansard, (18 August 2016) at 4876; Western Australia, Legislative Council, Hansard, (18 August 2016) at 4806.

84 Western Australia, Legislative Assembly, Hansard, (25 August 2016) at 5318; Western Australia, Legislative Council, Hansard, (25 August 2016) at 5238. 
Figure 4 - Outcome of parliament-led post-legislative scrutiny

\begin{tabular}{|c|c|c|c|c|}
\hline & $\begin{array}{l}\text { Review of the } \\
\text { State } \\
\text { Administrative } \\
\text { Tribunal Act } \\
\text { 2004 }\end{array}$ & $\begin{array}{l}\text { Review of the } \\
\text { Racing and } \\
\text { Wagering } \\
\text { Western } \\
\text { Australia Act } \\
2003\end{array}$ & $\begin{array}{l}\text { Review of the } \\
\text { Financial } \\
\text { Management } \\
\text { Act } 2006\end{array}$ & $\begin{array}{l}\text { Review of the } \\
\text { Auditor } \\
\text { General Act } \\
2006\end{array}$ \\
\hline $\begin{array}{l}\text { Total } \\
\text { recommendations }\end{array}$ & 60 & 53 & 10 & 24 \\
\hline $\begin{array}{l}\text { Recommendations } \\
\text { accepted/supported/su } \\
\text { pported in principle }\end{array}$ & 37 & 20 & 4 & 9 \\
\hline $\begin{array}{l}\text { Recommendations not } \\
\text { accepted/supported }\end{array}$ & 3 & 4 & 5 & 11 \\
\hline $\begin{array}{l}\text { Recommendations } \\
\text { subject to further } \\
\text { review Noted Not } \\
\text { applicable }\end{array}$ & 21 & 29 & 1 & 4 \\
\hline $\begin{array}{l}\text { Recommendations for } \\
\text { legislative reriew }\end{array}$ & 36 & 21 & 7 & 19 \\
\hline $\begin{array}{l}\text { Recommendations for } \\
\text { legislative review } \\
\text { implemented }\end{array}$ & 8 & 1 & 0 & 0 \\
\hline $\begin{array}{lr}\text { Mean time } & \text { for } \\
\text { implementation } & \text { of } \\
\text { legislative change } & \end{array}$ & 55 months & 88 months & - & - \\
\hline
\end{tabular}

\section{g. Discussion}

The timing of the inquiries in the case studies and the breadth of participants are largely consistent with the guiding principles of the Westminster Foundation for Democracy. However, little can be discerned as to the rationale behind the decisions to provide for parliamentary-led reviews of legislation and the scope of such reviews. There is a lack of specific processes addressing post-legislative scrutiny.

There are also very few measurable legislative outcomes achieved from postlegislative scrutiny in Western Australia. A comparison of the costs and outcomes of this activity could lead observers to question the merits of post-legislative scrutiny, particularly when time and resources are limited.

However, benefits must be accruing from post-legislative scrutiny in other jurisdictions, if measured solely by the number of jurisdictions undertaking this activity. 
In considering whether post-legislative scrutiny should form part of the legislative process in Western Australia, stakeholders may have regard for the barriers to further scrutiny activity. They may also consider and the potential effect on the outcomes of post-legislative scrutiny that could be generated through increasing Member's knowledge and engagement with post-legislative scrutiny and dedicated guidance on the scope and processes to be used for post-legislative scrutiny work.

\section{BARRIERS TO POST-LEGISLATIVE SCRUTINY}

Many of the barriers to increased post-legislative scrutiny are not unique to the Legislative Council of Western Australia. Proponents of post-legislative scrutiny argue that post-legislative scrutiny is a core part of a parliament's work and should be resourced accordingly. ${ }^{85}$ Convincing legislators of this, who are already timepoor, requires the value proposition of post-legislative scrutiny to be clearly articulated. In Western Australia the key barriers to post-legislative scrutiny are time, resourcing, access to information and political will.

\section{Time constraints}

A great constraint on a parliament's ability to perform its role is the competing demands upon its Members' time. Parliamentarians' time is already shared between parliamentary sittings, preparation for parliamentary debates, committee responsibilities and extensive constituency work. A study of the time commitments of Members of the Australian Federal Parliament revealed that Members self-report working between 6.2 and 6.4 days per week across sitting and non-sitting weeks. ${ }^{86}$ On sitting days, more than 90 per cent of Australian Senators interviewed reported working between 12 and 19 hours a day. ${ }^{87}$

Such are the demands on Members that additional committee work can lead to a lack of preparation or lack of participation. This can lead to inadequate questioning impacting on the quality of committee outputs, sporadic attendance, relying on others and over-reliance on the committee secretariat to progress the matters before the committee. ${ }^{88}$

85 Westminster Foundation for Democracy, supra note 28 at 8.

86 Parliament of Australia, What Lies Beneath: The Work of Senators and Members in the Australian Parliament, by Dr Scott Brenton (Canberra: Parliament of Australia, 2009) at 27.

87 Ibid at 29-30.

88 Constitution Unit, Selective Influence: The Policy Impact of House of Commons Select Committees, (London: Constitution Unit 2011) at 92. 


\section{Resources}

With limited government appropriations there is little flexibility for the Legislative Council to scale up and scale down its human resources as demand for committees increases and decreases. This leads to a natural limit to the number of inquiries that can be conducted at any one time. The impact of this is that post-legislative scrutiny work by committees has to compete with the priorities of the 36 Members to call inquiries into matters that are relevant to their political or constituency interests. There is scope for the Legislative Council to seek additional funding from the government for additional workload, however there may be some reticence from the government to increase funding for a greater level of scrutiny by parliament.

An alternative to post-legislative scrutiny by a parliamentary committee is the commissioning of a review by consultants on the impact of legislation, similar to the approach adopted for the review of the Auditor General Act 2006. However, this approach is generally far more expensive than a parliamentary review, where the costs of Members are sunk costs. Cost was a significant factor in the lateness of the review of the Auditor General Act 2006. In addition, a consultant will not have the powers and privileges of the parliament, will not be able to compel the production evidence and protect those giving evidence to a review. This approach also does not obviate the need for a committee to consider and report on the consultant's review.

\section{Access to information}

As in most Westminster democracies, there is a longstanding tension between the Western Australian Legislative and Executive branches of government concerning parliamentary scrutiny of the actions of the Executive. The legislature asserts its rights to compel the production of almost any documents held by Ministers or their departments in the name of parliamentary scrutiny. ${ }^{89}$ In doing so it invokes the privileges, powers and immunities of the House of Commons as expressly incorporated by the Parliamentary Privileges Act 1891, expressed in the following terms in Erskine May, 'There is no restriction on the power of committees to require the production of papers by private bodies or individuals, provided such papers are relevant to the committee's work, as defined by its order of reference'. ${ }^{90}$ The Executive maintains its arguments to resist requests for disclosure of Cabinet documents and documents claimed to be subject to public interest immunity and legal professional privilege. There is no independent body that can assess the veracity of such claims.

89 Legislative Council of Western Australia, Standing Committee on Estimates and Financial Operations, Provision of Information to the Parliament (19 May 2016) at 19 (Chair: Hon Ken Travers).

90 Boulton, C J, ed, Erskine May's Treatise on the Law, Privileges, Proceedings and Usage of Parliament, (London: Butterworths 1989) at 630. 
In some Australian jurisdictions, the limits of the legislature's power to compel documents has been tested in the courts. ${ }^{91}$ The result in jurisdictions such as New South Wales is that the legislature can compel production of almost all government documents, with the exception of documents produced explicitly for the deliberations of Cabinet.

Access to government documents is critical in post-legislative review when assessing the effectiveness and operation of a law. If the government does not support or wants to minimise the impact of a review, relevant documents could be withheld. This barrier could be addressed through a bipartisan approach to postlegislative scrutiny, a clear framework for the review process and trust in the process and possible outcomes.

\section{Standing Orders}

There are no Standing Orders that explicitly refer to post-legislative scrutiny in the Legislative Council. Likewise, the only relevant term of reference of a standing committee is the Joint Audit Committee's term of reference to conduct reviews of the Financial Management Act 2006 and the Auditor General Act 2006.

Despite this, there are three mechanisms in the Standing Orders to enable a committee to conduct post-legislative scrutiny. Firstly, a select committee can be created on a motion in the House, which must include the terms of reference of the committee and any procedures relevant to the operation of the committee. ${ }^{92}$ Secondly, the House can use its general powers to refer any matter to an existing committee for inquiry. Finally, several standing committees have own-motion powers to inquire into matters that are relevant to their remit. ${ }^{93}$ It is arguable that these committees can conduct inquiries into the implementation of legislation, although such reviews might duplicate reviews conducted by the Executive.

In the absence of any Standing Orders or guidance as to the process and scope of post-legislative scrutiny, any ad hoc inquiries or use of own-motion powers could result in further inconsistent processes and outcomes.

\section{Political will}

Prior to the adoption of a systematic process of post-legislative scrutiny in the United Kingdom the Law Commission identified that, 'The evolution of more systematic approaches to post-legislative scrutiny will depend on a combination of political will and judgement. ${ }^{94}$ Such a combination was found in the United Kingdom.

\footnotetext{
91 Egan v Chadwick (1999) 40 NSWLR 650.

92 Legislative Council of Western Australia, supra note 33 at SO 157.

93 Ibid at Sch 1.

94 The Law Commission, supra note 3 at 2.15.
} 
The biggest impediment to further post-legislative scrutiny by the parliament in Western Australia is likely to be the will of Members. Parliamentary debates do not demonstrate that Members have a deep knowledge of the process and benefits of post-legislative scrutiny. In the last 20 years, the words 'post-legislative scrutiny' have been spoken four times in the Legislative Council, and on three of those occasions Members were quoting the same source. ${ }^{95}$ More broadly, in Australia, there has been very little interest in post-legislative scrutiny by parliament. ${ }^{96}$ However, the number of amendments moved to bills to include review clauses suggests that Members are interested in ensuring that Acts are considered in the future to ensure they are operating effectively.

To embrace the idea of post-legislative scrutiny, Members will need to see that there are tangible benefits to come from the activity, beyond the primary benefits of improvements to existing laws identified in Executive-led reviews. A challenge will be demonstrating the secondary benefits of improvements to the law-making process that can be used to enhance future law-making and pre-legislative scrutiny.

Post-legislative scrutiny will only be a success if the relationship between the Legislative and Executive branches of government is robust. ${ }^{97}$ Evaluation is an inherently political exercise and can lead to praise or blame being laid on the government. ${ }^{98}$ Parliament will be unable to perform its post-legislative role without access to people, documents and funding. The Executive will be resistant to further scrutiny by parliament if the legislature over-steps reasonable boundaries of inquiry, rehashes prior arguments over the policy of the law or politicises the process. Ultimately, the legislature is dependent on the Executive-controlled government to introduce amending laws into parliament as the government controls the legislative agenda. This forms a natural check on the relationship between the two branches of government.

\section{A PATH FORWARD FOR WESTERN AUSTRALIA}

Many of the components of post-legislative scrutiny are already in place in Western Australia but there are gaps in knowledge and process that, if filled, could provide a more rigorous system of scrutiny with little change to established norms and mechanisms. However, if there was a desire amongst Members to introduce a more rigorous, formal post-legislative review process, a significant amount of work would need to be undertaken to determine a model that is fit-for-purpose, cost-effective and able to demonstrate value for money for the benefits it produces.

95 Western Australia, Legislative Council, Hansard, (1 December 2011) at 10297 (Hon Adele Farina).

96 Francis, supra note 16 at 85.

97 Koen Van Aeken, "From Vision to Reality: Ex Post Evaluation of Legislation" (2011) 5(1) Legisprudence 41 at 67.

98 Stijn van Voorst \& Pieter Zwaan, "The (non-) use of ex post evaluation by the European Commission” (2019) 26(3) Journal of European Public Policy 366 at 368. 


\section{Enhancing Knowledge of Scrutiny Processes}

The limited level of engagement of Members with Executive-led reviews tabled in parliament and post-legislative scrutiny work conducted by parliamentary committees could be a function of lack of knowledge and technical skills concerning legislative scrutiny. As the review process commences with the passing of the original Act, training could be provided to Members on the life-cycle of legislation with a focus on the construction of review clauses. This training could also inform Members of the possibilities in relation to post-legislative review and lead to further scrutiny during the passage of bills through questions to Ministers on the policy objectives of bills. Information on review clauses in legislation could be collated by the parliamentary staff or the parliamentary library and made available to Members.

As Members are better informed on the opportunities and benefits of postlegislative scrutiny, an informed debate could be had as to whether the current ad hoc review processes are meeting the needs of Members.

\section{Minor Changes to Current Arrangements}

Minor changes to existing scrutiny arrangements could result in enhanced scrutiny outcomes in Western Australia.

Under current standing orders, it is open to the House to refer any matter to a committee for consideration and report. With an average of three Executive-led reviews tabled each year, it would be open and feasible for some of these reviews to be referred to a committee for review of these documents, similar to the process in the United Kingdom. ${ }^{99}$ Individual parliamentary committees could also consider their responsibilities relating to post-legislative scrutiny and consider whether they could report to the House on Executive-led reviews that are incomplete, late or of poor quality. The Uniform Legislation and Statutes Review Committee has a function to review the form and content of the statute book, which could capture this activity. ${ }^{100}$

Committees could also work with representatives of Executive government to determine standards and guidelines for reviews. This could lead to consistency in approach for both parliament-led and Executive-led reviews.

\section{More comprehensive reform}

If further reform is called for, further research needs to be undertaken into the Western Australian context of legislative review including identifying the current

99 Tom Caygill, "A Tale of Two Houses - Post-Legislative Scrutiny in the UK Parliament" (2019) 21(2) European Journal of Law Reform 87 at 87.

100 Legislative Council of Western Australia, supra note 33 at Sch 1. 
weakness in the legislative process and any inherent problems or gaps in scrutiny. This research could include consultation with Members, the Executive, government and non-government agencies and expert groups. If change is to occur to scrutiny mechanisms, the benefits of such changes will need to be clearly articulated.

Any change to the scrutiny process would need to be inclusive and realistic in light of the broader work of parliament. ${ }^{101}$ If the argument can be successfully made that post-legislative scrutiny would enhance the law-making process and the outcomes of this activity would be superior to the existing system, then political will is likely to follow.

\section{Enhancing corporate knowledge}

Irrespective of whether any change occurs to the mechanism of post-legislative scrutiny in Western Australia, the Legislative Council has an institutional obligation to ensure that it is aware of contemporary approaches and best-practice to postlegislative scrutiny. Such work may include the development of a model for committee-led select committees to conduct post-legislative scrutiny and how such inquiries might differ from other inquiries.

It is widely recognised that there is great value in the institutionalisation of evaluation and one body with an 'eagle's eye' over what is scrutinised. ${ }^{102}{ }^{103}$ With parliament's frequently changing membership, this knowledge must primarily rest with the professional staff of the parliament who will be the custodians of this work. By investing in its people, the Legislative Council can ensure that parliamentary committees are well positioned to conduct further post-legislative scrutiny and ensure that it is tailored and not mechanistic. ${ }^{104}$

\section{CONCLUSION}

Despite no formal established program of post-legislative scrutiny in Western Australia, there is ad hoc post-legislative scrutiny occurring through Executive-led reviews and occasional review by parliamentary committees. However, this approach has led to limited outcomes in terms of completion of reviews, timeliness of reviews, legislative change and consideration in the parliamentary chamber.

The push towards greater levels of post-legislative scrutiny around the world and time that some systems of post-legislative review have been in place means there is a growing body of evidence and best practice that Western Australia could tap into in assessing how post-legislative scrutiny could improve legislative processes.

101 Hansard Society, Briefing Paper: Issues in Law Making - Post-Legislative Scrutiny, (London: Hansard Society, 2005) at 6.

102 Mader, supra note 25 at 130.

103 Francis, supra note 16 at 93.

104 “Post Legislative Scrutiny [Editorial]” (2006) 27(2) Statute Law Review iii at iii. 


\section{BIBLIOGRAPHY}

Administrative Decisions Tribunal Act, New South Wales 1997.

Boulton, C J, ed, Erskine May's Treatise on the Law, Privileges, Proceedings and Usage of Parliament, (London: Butterworths 1989).

Caygill, Tom, "A Tale of Two Houses - Post-Legislative Scrutiny in the UK Parliament” (2019) 21(2) European Journal of Law Reform 87.

Chauvel, Charles, "Post-Legislative Scrutiny in New Zealand - A Focus on Delegated Legislation” (2019) 21(2) European Journal of Law Reform 169.

Constitution Acts Amendment Act, Western Australia 1899.

Constitution Unit, Selective Influence: The Policy Impact of House of Commons Select Committees, (London: Constitution Unit 2011).

Egan v Chadwick (1999) 40 NSWLR 650.

Finlayson, Christopher, "Making better law in New Zealand" (2006) 3 The Parliamentarian 232.

Francis, Angus, "The Review of Australia's Asylum Laws and Policies: A case for Strengthening Parliament's Role in Protecting Rights Through PostEnactment Scrutiny" (2008) 32(1) Melbourne University Law Review 83.

Griglio, Elena, "Post-Legislative Scrutiny as a Form of Executive Oversight" (2019) 21 (2) European Journal of Law Reform 118.

Hansard Society, Briefing Paper: Issues in Law Making - Post-Legislative Scrutiny, (London: Hansard Society, 2005).

House of Commons, Select Committee on Liaison, Annual Report for 2002 (20 March 2003) (Chair: Alan Williams).

House of Commons, Select Committee on Procedure, The Process of Legislation, (28 July 1971) (Chair: Robin Turton).

House of Commons, Select Committee on the Modernisation of the House of Commons, $1^{\text {st }}$ Report on the Legislative Process (29 July 1997) (Chair: Ann Taylor).

House of Lords, Select Committee on the Constitution, Parliament and the Legislative Process, (29 October 2004) (Chair: Lord North of Nouth).

Land Legislation Amendment (Taxing) Act, Western Australia 2014.

Legislation Act, Commonwealth of Australia 2003.

Legislative Assembly of Western Australia, Public Accounts Committee, Review of the Financial Management Bill 2005 and the Auditor General Bill 2005, (6 April 2006) (Chair: John Quigley). 
Legislative Council and Legislative Assembly of Western Australia, Joint Standing Committee on Audit, Review of the Auditor General Act - Appointment of Reviewer, (17 October 2013) (Chair: Hon Ken Travers).

Legislative Council and Legislative Assembly of Western Australia, Joint Standing Committee on Audit, Review of the Department of Treasury's Review of the Financial Management Act 2006, (17 March 2016) (Chair: Hon Ken Travers).

Legislative Council and Legislative Assembly of Western Australia, Joint Standing Committee on Audit, Review of the Operation and Effectiveness of the Auditor General Act 2006, (25 August 2016) (Chair: Hon Ken Travers).

Legislative Council and Legislative Assembly of Western Australia, Joint Standing Committee on The Review of the Racing and Wagering Western Australia Acts, Inquiry into the Racing and Wagering Western Australia Acts, (14 October 2010) (Chair: John McGrath).

Legislative Council of Western Australia, Standing Committee on Estimates and Financial Operations, Provision of Information to the Parliament (19 May 2016) (Chair: Hon Ken Travers).

Legislative Council of Western Australia, Standing Committee on Legislation, Inquiry into the Jurisdiction and Operation of the State Administrative Tribunal, (20 May 2009) (Chair: Hon Ken Baston).

Legislative Council of Western Australia, Standing Committee on Legislation, State Administrative Tribunal Bill 2003 and the State Administrative Tribunal (Conferral of Jurisdiction) Amendment and Repeal Bill 2003, (29 October 2004) (Chair: Hon Jon Ford).

Legislative Council of Western Australia, Standing Orders

Legislative Standards Act, Queensland 1992.

Mader, Luzius,"Evaluating the Effects: A Contribution to the Quality of Legislation" (2001) 22(2) Statute Law Review 119.

Murphy, Jonathan \& Mishura, Svitlana, "Post Legislative Scrutiny in a NonWestminster Environment” (2019) 21(2) European Journal of Law Reform 102.

Mutual Recognition (Western Australia) Act, Western Australia 2010.

Office of the Leader of the House of Commons, Post-legislative Scrutiny - The Government's Approach, (London: Office of the Leader of the House of Commons, 2008) online: https://assets.publishing.service.gov.uk/government/uploads/system/uploads/a ttachment_data/file/228516/7320.pdf.

Palmer, Geoffrey, "Law-Making in New Zealand: Is There a Better Way" (2014) 22 Waikato Law Review 1. 
Parliament of Australia, What Lies Beneath: The Work of Senators and Members in the Australian Parliament, by Dr Scott Brenton (Canberra: Parliament of Australia, 2009).

"Post Legislative Scrutiny [Editorial]" (2006) 27(2) Statute Law Review iii.

Suitors' Fund Amendment Bill, Western Australia 2017.

Terrorism (Extraordinary Powers) Act, Western Australia 2005.

United Kingdom, The Law Commission, Post-Legislative Scrutiny, (London: The Law Commission, 2006).

Van Aeken, Koen, "From Vision to Reality: Ex Post Evaluation of Legislation" (2011) 5(1) Legisprudence 41.

Van Voorst, Stijn \& Zwaan, Pieter, "The (non-) use of ex post evaluation by the European Commission” (2019) 26(3) Journal of European Public Policy 366.

Western Australia, Commission on Government, Report No.2, (Perth: Commission on Government, 1995) online: <https://www.slp.wa.gov.au/publications/publications.nsf/DocByAgency/D706 5CDD58C787544825698300109D09/\$file/report2.pdf $\geq$.

Western Australia, Department of Treasury, Budget Paper No.2 Volume 2, (Perth: Department of Treasury, 2019).

Western Australia, Public Sector Commission, Guidelines for the Review of Legislation, (Perth: Public Sector Commission, 2013).

Western Australia, Regulatory Gatekeeping Unit, Regulatory Impact Assessment Guidelines for Western Australia, (Perth: Regulatory Gatekeeping Unit, 2010).

Westminster Foundation for Democracy, Post-Legislative Scrutiny: Comparative study of practices of Post-Legislative Scrutiny in selected parliaments and the rationale for its place in democracy assistance, (London: Westminster Foundation for Democracy, 2017) by Franklin De Vrieze and Victoria Hasson.

Westminster Foundation for Democracy, Principles of Post-Legislative Scrutiny by Parliaments, (London: Westminster Foundation for Democracy, 2018) by Franklin De Vrieze.

Hon Kate Doust MLC is the President of the Legislative Council of Western Australia and was first elected in 2001. She was elected President of the Legislative Council in May 2017 and is the first woman to be elected to that role. Her research interests include the analysis of the parliament as a civic institution, legislative scrutiny and the use of technology to aid the work of parliaments. Ms Doust holds a Bachelor of Arts from the University of Western Australia. 
Mr Sam Hastings is the Clerk Assistant (House) for the Legislative Council of Western Australia. He holds a Bachelor of Laws and a Bachelor of Economics from Murdoch University. He has extensive experience in public law and government administration. Mr Hastings researches in the areas of legislative scrutiny and parliamentary privilege. The authors acknowledge the research assistance provided by Ms Renae Jewell, Ms Kristina Crichton, Ms Maddison Evans and Ms Clair Siva. 